\title{
PENERAPAN MODEL PEMBELAJARAN KOOPERATIF TIPE TGT (TEAM GAME TOURNAMENT) DENGAN METODE TUTOR SEBAYA UNTUK MENUNTASKAN HASIL BELAJAR SISWA PADA KELAS X IPA 6 SMAN 2 PAMEKASAN
}

\author{
Mabruratul Hasanah' ${ }^{1}$, Khalifatur Rahman \\ ${ }^{1)}$ SMA 2 Pamekasan Madura, Indonesia
}

\begin{abstract}
This research background of their learning outcomes, student of class X IPA 6 SMAN 2 Pamekasan who have not yet reached KKM particularly in the field of physics studies. Therefore, the researchers tried to use cooperative learning model TGT method peer tutor in class X IPA 6 SMAN 2 Pamekasan on the subject Heat and Heat Transfer. The problems of this study are: 1). How completeness of student learning outcomes through the implementation of cooperative learning model TGT method peer tutor in class X IPA 6 SMAN 2 Pamekasan?. 2). How the student's activity during the implementation of cooperative learning model TGT method peer tutor in class X IPA 6 SMAN 2 Pamekasan ?. The purpose of this study is : 1). To Finalising the student learning outcomes through the implementation of cooperative learning model TGT method peer tutors. 2). To determine the students' learning activities during the implementation of cooperative learning model TGT method peer tutors on the subject Heat and Heat Transfer. This research is a classroom action research. The experiment was conducted three cycles, with each cycle consisting of planning, implementation, observation, evaluation, and reflection. Subjects were students ofclass XIPA 6 SMAN 2 Pamekasan in academic year 2014/2015. The data analysis technique used is descriptive statistics. From the analyst found that the learning outcomes of students from the first cycle to cycle III has reached completeness criteria with a percentage that is, the first cycle (50\%), the second cycle (70\%), Cycle III $(85 \%)$ and student activity in accordance with the purpose of learning cooperative. The results of the evaluation of the pretest-posttest is from $10.00 \%$ (not exhaustive) to $90.00 \%$ (complete). Thus, it can be concluded that the type cooperative learning TGT Method Peer Tutor can complete physics learning outcomes and student activity IPA 6 Class X SMAN 2 Pamekasan on the subject Heat and Heat Transfer.
\end{abstract}

Keywords: TGT, Learning Outcomes, Heat and Heat Transfer.

\begin{abstract}
Abstrak
Penelitian ini berlatar belakang adanya hasil belajar siswa kelas X IPA 6 SMAN 2 Pamekasan yang belum mencapai KKM hususnya dalam bidang studi fisika. Oleh karena itu, peneliti mencoba menggunakan model pembelajaran kooperatif tipe TGT dengan metode tutor sebaya di kelas X IPA 6 SMAN 2 Pamekas an pada pokok bahasan Kalor dan Perpindahan Kalor. Permasalahan penelitian ini yaitu 1). Bagaimana ketuntasan hasil belajar siswa melalui penerapan model pembelajaran kooperatif tipe TGT dengan metode tutor sebaya pada kelas X IPA 6 SMAN 2 Pamekasan?. 2). Bagaimana aktivitas sis wa selama penerapan model pembelajaran kooperatif tipe TGT dengan metode tutor sebaya pada siswa kelas X IPA 6 SMAN 2 Pamekasan?.Tujuan Penelitian ini adalah 1). Untuk Menuntaskan hasil belajar siswa melalui penerapan model pembelajaran kooperatif tipe TGT dengan metode tutor sebaya. 2). Untuk mengetahui Aktivitas belajar siswa selama penerapan model pembelajaran kooperatif tipe TGT dengan metode tutor sebaya.pada pokok bahasan Kalor dan Perpindahan Kalor. Penelitian ini merupakan Penelitian Tindakan Kelas. Penelitian dilaksanakan tiga siklus, dengan tiap siklus terdiri atas perencanaan, pelaksanaan, pengamatan, evaluasi, dan refleksi. Subyek penelitian adalah siswa kelas X IPA 6 SMAN 2 Pamekasan tahun pelajaran 2014/2015. Analisis data yang digunakan adalah teknik statistik deskriptif. Dari hasil analis didapatkan bahwa hasil belajar siswa dari Siklus I sampai Siklus III sudah mencapai kriteria ketuntasan dengan persentase yaitu, Siklus I (50\%), Siklus II (70\%), Siklus III (85\%) dan aktivitas siswa telah sesuai dengan tujuan pembelajaran kooperatif. Hasil evaluasi pretes-postes yaitu dari 10,00\% (tidak tuntas) menjadi 90,00\%(tuntas). Dengan demikian, dapat disimpulkan bahwa pembelajaran kooperatif tipe TGT dengan
\end{abstract}


Metode Tutor Sebaya dapat menuntaskan hasil belajar fisika dan aktivitas siswa Kelas X IPA 6 SMAN 2 Pamekasan pada pokok bahas an Kalor dan Perpindahan Kalor.

Kata Kunci: TGT, Hasil Belajar, Kalor dan Perpindahan Kalor

DOI : http:/dx.doi.org/10.21067/mpej.v1i1.1632

Diterima: Januari 2017; Disetujui: Maret 2017

\section{PENDAHULUAN}

Pendidikan adalah aspek universal IPA 6 SMAN 2 PAMEKASAN ditemukan yang selalu dan harus ada dalam kehidupan bahwa hasil belajar siswa rendahpada mata manusia. Tanpa pendidikan ia tidak akan pelajaran fisika. Hal tersebut terbukti $65 \%$ pernah berkembang dan berkebudayaan. atau 13 siswa dari 20 siswa yang masih Disamping itu, kehidupan juga akan dibawah nilai Kriteria Ketuntasan Minimal mengalami statis tanpa ada kemajuan, (KKM) yaitu sebesar 72. Salah satu bahkan bisa jadi akan mengalami penyebabnya ialah tidak ada variasi model kemunduran dan kepunahan. Oleh karena pembelajaran dalam mengajar pada matei itu menjadi fakta yang tak terbantahkan perpindahan kalor, guru kurang melibatkan bahwa pendidikan adalah sesuatu yang siswa untuk melakukan praktikum, dan niscaya dalam kehidupan (Indriani, tidak adanya permainan dalam proses 2011:05).

pembelajaran sehingga siswa merasa

Dalam jenjang pendidikan, Pelajaran bosan/tidak tertarik pada pelajaran. Hal ini IPA merupakan salah satu pelajaran pokok. terlihat juga dalam interaksi antar siswa, Pelajaran ini merupakan salah satu siswa tidak saling berdiskusi, siswa malu pelajaran yang menjadi standar kelulusan dalam mengemukakan pendapat, siswa para siswa, sehingga para pendidik harus jarang bertanya pada guru, dan siswa lebih berusaha secara maksimal untuk belajarnya masih individual.

membuat siswa mengerti dan paham pada Untuk itu, peneliti memberi penawaran materi IPA. Namun, fenomena yang terjadi model pembelajaran kooperatif tipe TGT di lapangan walaupun mereka sudah dengan menggunakan metode tutor sebaya. berusaha tapi masih banyak siswa yang Pembelajaran kooperatif adalah rangkaian tidak menguasai IPA dan menganggap kegiatan belajar pada siswa dalam pelajaran tersebut sangat sulit.

kelompok-kelompok tertentu untuk

Berdasarkan hasil observasi di kelas $\mathrm{X}$ mencapai tujuan pembelajaran yang telah

* Corresponding Author: dirumuskan (Sanjaya, 2009:241). mabruratulhasanah@gmail.com 
Pembelajaran kooperatif tipe TGT adalah cara-cara yang dilakukan pengajar lebih menekankan interaksi antar siswa. atau instruktur untuk menyajikan informasi Dari sini siswa akan melakukan atau pengalaman baru, menggali komunikasi aktif dengan temannya. pengalaman peserta belajar, menampilkan Dengan komunikasi tersebut diharapkan unjuk kerja peserta belajar dan lain-lain siswa dapat menguasai materi pelajaran (Uno, 2009).

dengan mudah karena siswa lebih mudah (Isjoni, 2009) menjelaskan bahwa memahami penjelasan dari kawannya model pembelajaran kooperatif memiliki dibanding penjelasan dari guru karena taraf enam tipe, yaitu (1) Student Team pengetahuan serta pemikiran mereka lebih Achievement Division (STAD), (2) Jigsaw, sejalan dan sepadan.

(3) Teams Games Tournaments (TGT), (4)

Model pembelajaran tipe TGT adalah Group Investigation (GI), (5) Rotating Trio salah satu tipe dalam pembelajaran Exchange dan (6) Group Resume. Dari kekooperatif yang mudah diterapkan, enam tipe pembelajaran tersebut yang melibatkan aktivitas seluruh siswa tanpa dirasakan cukup efektif oleh peneliti adalah harus ada perbedaan status, melibatkan tipe TGT. TGT menyatakan bahwa lebih peran siswa sebagai tutor sebaya serta dari $60 \%$ respon siswa senang terhadap mengandung unsur permainan dan model pembelajaran TGT dan ketuntasan reinforcement. Aktivitas belajar dengan belajar siswa, baik secara individu maupun permainan yang dirancang dalam secara klasikal melebihi standar kriteria pembelajaran kooperatif tipe Team Games ketuntasan minimal (tuntas). Hal ini Tournaments (TGT) memungkinkan siswa terbukti 31 siswa yang tuntas dari 35 siswa dapat belajar lebih rileks disamping secara individu sedangkan secara klasikal menumbuhkan tanggung jawab, kejujuran, mencapai $92 \%$.

kerja sama, persaingan sehat dan Penelitian sebelumnya oleh (Suri, keterlibatan belajar.

2010) juga menyatakan Hasil belajar siswa

Metode Tutor sebaya adalah siswa pada Siklus I ke Siklus II mengalami yang ditunjuk atau ditugaskan membantu peningkatan sebesar $20 \%$ dan dari Siklus II teman-temannya yang mengalami kesulitan ke Siklus III mengalami peningkatan belajar, karena hubungan antar teman sebesar $15 \%$ dengan rata-rata nilai pada umumnya lebih akrab dibandingkan Siklus I sebesar 63,5; pada Siklus II sebesar hubungan guru dengan siswa (Muhammad, 70 dan pada Siklus III sebesar 72,5. Dari 2011). Metode pembelajaran tutor sebaya hasil penelitian tersebut terlihat bahwa 
hasil belajar siswa secara klasikal telah tercapai $85 \%$ pada Siklus ke III atau sudah dapat dikatakan tuntas. Sedangkan respon siswa terhadap penerapan model pembelajaran kooperatif tipe TGT adalah positifatau senang dengan penerapan model pembelajaran tersebut. Hal ini terbukti bahwa hasil perhitungan persentase repon siswa melebihi dari kriteria respon positif (60\%) yaitu sebesar $82,33 \%$.

Berdasarkan hasil penelitian Retyno (2013) memperoleh bahwa dengam metode tutor sebaya dapat meningkatkan prestasi siswa dengan hasil tes pada siklus I sebesar $46,7 \%$, siklus II sebesar 66,7\%, siklus III sebesar 68,7\%. Yang dibuktikan dengan adanya peningkatan kemampuan siswa dari sesudah penerapan metode tutor sebaya yaitu siklus I 7 siswa, siklus II 10 siswa, siklus III 13 siswa yang memenuhi KKM dengan nilai 70. Dengan metode pembelajaran ini telah memperoleh ketuntasan kelas, terbukti siswa dapat mencapai KKM yang telah ditentukan $>85 \%(86,7 \%$.).

\section{METODE PENELITIAN}

Subyek penelitian pada penelitian ini 1 adalah siswa kelas $\mathrm{X}$ IPA-6 SMAN 2 Pamekasan. Dilaksanakan di SMAN 2 sebelum proses pembelajaran kooperatif Pamekasan pada Siswa Kelas X IPA-6 tipe TGT dengan Metode Tutor sebaya Semester Genap Tahun Pelajaran 2014- dimulai, bahwa sebelum diberikan

2015. Proses pengumpulan data dalam penelitian ini direncanakan terdiri dari tiga siklus dengan empat tahapan pada masingmasing siklusnya. Tiap tahapan dalam satu siklus dilaksanakan, kemudian hasilnya digunakan untuk memperbaiki siklus berikutnya secara terus-menerus, sehingga ketuntasan belajar siswa fisika dengan menggunakan model pembelajaran kooperatif tipe TGT pada pokok bahasan Perpindahan Kalor semakin meningkat.

Penelitian ini mengikuti prosedur kerja yang bersifat siklus spiral yang didesain oleh Kemmis \& Mc Taggart (Arikunto, 2011), meliputi fase: perencanaan, pelaksanaan tindakan, observasi dan evaluasi, dan refleksi yang diikuti dengan perencanaan ulang.

\section{HASIL DAN PEMBAHASAN}

Data penelitian yang diperoleh berupa data persiklus yang terdiri dari hasil pretes (Hasil Ulangan Harian Materi sebelum Siklus 1), tes formatif, observasi dan data skor. Kemudian hasil data tersebut dianalisis.

Adapun hasil dan analisis data tersebut diantaranya sebagai berikut:

1. Hasil dan Analis is Pretes Siswa

Berdasarkan pretes yang dilakukan 
perlakuan hanya terdapat 13 siswa yang mengajar terdiri dari beberapa tahapan tuntas dan 19 siswa tidak tuntas dengan berikut:

nilai dibawah 72. Hal ini menunjukkan Pendahuluan

bahwa model pembelajaran yang Guru memotivasi siswa dengan digunakan sebelum siklus 1 kurang demonstrasi memanasan air didalam gelas maksimal. plastik. Kemudian guru bertanya mengapa

2. Hasil dan Analisis Data Persiklus

a. Siklus I

1). Tahap Perencanaan

Pada tahap ini peneliti ingin dicapai.

mempersiapkan semua perlengkapan yang Kegiatan Inti

diperlukan selama kegiatan belajar

(1) Guru menerangkan sedikit materi mengajar dengan menggunakan model pokok sebagai pengetahuan awal pembelajaran kooperatif tipe TGT dengan Tutor Sebaya. Perlengkapan tersebut terdiri dari:

a. Perangkat pembelajaran seperti: Silabus, Rencana Pelaksanaan Pembelajaran (RPP), Buku Siswa, Lembar Kerja Siswa (LKS) dan Soal Permainan.

b. Alat-alat yang akan digunakan dalam percobaan.

c. Instrumen penelitian seperti: lembar keterlaksanaan RPP, lembar aktivitas siswa, dan lembar evaluasi. siswa.

(2) Guru membagi siswa menjadi enam kelompok yang masing-masing kelompok beranggotakan 4 orang yang heterogen.

(3) Guru menunjuk siswa yang berkemampuan lebih untuk menjadi ketua kelompok dan menjadi tutor sebaya pada kelompoknya.

(4) Ketua kelompok memberi penjelasan materi yang sudah disampaikan guru kepada anggota kelompoknya

(5) Guru membagikan buku siswa dan LKS.

2). Tahap pelaksanaan tindakan

Pelaksanaan kegiatan belajar

(6) Guru membimbing siswa dalam mengajar untuk Siklus I dilaksanakan pada tanggal 14 Maret 2015 di Kelas X IPA 6 SMAN 2 Pamekasan dengan jumlah siswa 20 siswa. Dalam hal ini peneliti bertindak sebagai guru. Adapun proses belajar mengerjakan lembar kerja siswa untuk kemudian didiskusikan bersama anggota kelompoknya.

(7) Guru meminta siswa untuk mempresentasikan hasil LKS. 
(8) Guru membagi siswa kedalam hanya sebesar 50\% lebih kecil dari beberapa meja dan membimbing persentase ketuntasan yang dikehendaki Siswa memainkan pertandingan yaitu sebesar 85\%. Hal ini disebabkan akademik.

karena siswa masih merasa baru dan belum

(9) Guru memberikan siswa kartu mengerti apa yang dimaksudkan dan bernomor yang berisi pertanyaan- digunakan guru dengan menerapkan model pertanyaan dan menjelaskan cara pembelajaran kooperatif tipe TGT dengan bermain dengan kartu bernomor. metode Tutor Sebaya.

(10) Guru memberi lembar evaluasi siswa.

\section{Penutup}

(1) Guru memberi kesempatan kepada siswa untuk menanyakan hal-hal yang belum dimengerti

(2) Guru bersama siswa membuat kesimpulan akhir

3). Tahap Evaluasi dan Pengamatan

Dari hasil tes evaluasi yang diberikan pada siswa menghasilkan data ketuntasan belajar siswa dapat diketahui $50 \%$. Dengan dihitung persentasenya (ketuntasan kelas) sebagai berikut:

$$
\text { Ketuntasan kelas }=\frac{16}{32} \times 100 \%=50 \%
$$

Dapat dijelaskan bahwa dengan menerapkan model pembelajaran kooperatif tipe TGT dengan tutor sebaya diperoleh nilai rata-rata prestasi belajar siswa adalah 62,5 dan ketuntasan belajar mencapai $50 \%$ atau ada 16 siswa dari 32 siswa sudah tuntas belajar. Hasil tersebut menunjukkan bahwa pada siklus pertama secara klasikal siswa belum tuntas belajar, karena siswa yang memperoleh nilai $\geq 65$
Selama kegiatan belajar mengajar berlangsung, dilakukan pengamatan pengelolaan pembelajaran kooperatif tipe TGT dengan tutor sebaya dan aktivitas siswa. Pengamatan ini dilakukan oleh dua observer yang sudah terlatih. Hasil penilaian lembar pengelolaan pembelajaran dan aktivitas siswa pada putaran pertama dapat dilihat pada Tabel 1 dan Tabel 2 berikut ini:

Dari Tabel 1 di atas dapat diketahui nilai rata-rata termasuk kategori Kurang Baik, Dengan diperoleh nilai rata-rata 2,97. Dari Tabel 2. , iketahui bahwa aktivitas siswa selama KBM yang paling menonjol adalah membaca, mendengar penjelasan guru (mencari informasi dan sebagainya) dan yang paling rendah adalah mendiskusikan tugas/bekerjasama dengan baik dalam tim. 
Tabel 1 Data Pengamatan Pembelajaran 5. Bertanya kepada guru

Kooperatif tipe TGT dengan tutor sebaya Siklus I

\begin{tabular}{llrrrl}
\hline & NO & \multicolumn{4}{c}{ Pertemuan I } \\
& $\begin{array}{l}\text { Aspek yang } \\
\text { diamati }\end{array}$ & P1 & P2 & Rer & Kategori \\
& & & ata & \\
\cline { 1 - 4 } A & Pendahuluan & 3 & 3,5 & 3 & Cukup \\
B & Kegiatan inti & 2 & 3 & 2 & kurang \\
C & Penutup & 3 & 3,5 & 3 & Cukup \\
D & Pengelolaan & 2 & 3 & 2 & kurang \\
& waktu & & & & \\
E & Pengelolaan & 2 & 3 & 2 & kurang \\
& KBM & & & & \\
\hline & Rata-rata & & & & \\
& & & & & \\
\hline
\end{tabular}

Tabel 2 Data Pengamatan Aktivitas Siswa Siklus I

\begin{tabular}{ccccccccc}
\hline $\mathbf{P}$ & \multicolumn{1}{c}{ Aktivitas Siswa } & & & Jml \\
& $\mathbf{1}$ & $\mathbf{2}$ & $\mathbf{3}$ & $\mathbf{4}$ & $\mathbf{5}$ & $\mathbf{6}$ & $\mathbf{7}$ & \\
\hline I & 10 & 4 & 7 & 10 & 6 & 5 & 8 & 50 \\
II & 11 & 3 & 8 & 10 & 5 & 5 & 10 & 52 \\
& & & & & & & & \\
\hline $\begin{array}{l}\text { Rata- } \\
\text { rata }\end{array}$ & 10 & 3 & 7 & 10 & 5 & 5 & 9 & 51 \\
\hline $\begin{array}{l}\text { Perse } \\
\text { ntase }\end{array}$ & 20 & 6 & 14 & 19 & 10 & 9 & 13 & 100 \\
\hline
\end{tabular}

Keterangan:

1. Membaca, mendengar penjelasan guru (mencari informasi dan sebagainya)

2. Mendiskusikan tugas/bekerjasama dengan baik dalam tim

3. Melakukan percobaan dan pengamatan dengan menggunakan alat yang sudah ditentukan

4. Melakukan Permainan dengan kartukartu bernomor
6. Mempresentasikan hasil percobaan dan pengamatan dengan baik.

7. Menyampaikan

pendapat/mengomunikasikan

informasi kepada kelas atau guru

4). Tahap Refleksi

Setelah tahap kegiatan dan pengamatan, diperoleh gambaran tentang kekurangan yang terjadi pada putaran pertama sebagai berikut:

a) siswa kurang maksimal dalam hasil belajar dimana ketuntasan kelas yang dicapai masih 50\%, artinya kelas masih belum dikatakan tuntas. sedangkan kelas bisa dikatakan tuntas apabila ketuntasan kelasnya sudah mencapai $85 \%$.

b) Dalam Kegiatan Inti Guru masih kurang dalam mengorganisasikan siswa dalam kelompok belajar dengan baik, dan Guru masih kurang teliti dalam membimbing kerja kelompok dan percobaan siswa, sehingga siswa masih ramai dan masih merasa kesulitan dalam percobaan.

c) Siswa pada siklus ini belum maksimal dalam mendiskusikan tugas/bekerjasama dengan baik dalam kelompok.

d) Siswa masih bingung dalam pelaksanaan Permainan 


\section{5). Tahap Revisi}

Kekurangan-kekurangan yang terjadi pada pertemuan pertama di atas akan dijadikan masukan untuk dilakukan revisi pada pertemuan kedua yaitu:

a) Guru memaksimalkan pembelajaran kooperatif sehingga pembelajaran ketuntasan kelas bisa tercapai.

b) Mengorganisasikan siswa dalam kelompok belajar dengan baik dan lebih teliti dalam membimbing kerja kelompok dan percobaan siswa.

c) Mengelola waktu dengan baik sehingga waktu yang tersedia dapat berjalan dengan efektif.

d) Memaksimalkan aktivitas siswa dengan memberi nasehat bahwa mereka harus bekerjasama dalam kelompoknya masing-masing.

e) Guru memberi contoh cara melaksanakan Permainan

b. Siklus II

1) Tahap perencanaan

Pada siklus kedua ini tahap perencanaan dilakukan berdasarkan revisi pada siklus pertama. Adapun hal-hal yang perlu diperbaiki adalah sebagai berikut:

a) Aktivitas siswa.

b) Kemampuan guru dalam menguasai kelas.

c) Kemampuan guru mengorganisasikan siswa dalam kelompoknya dan teliti dalam membimbing kerja kelompok dan percobaan siswa.

d) Kemampuan guru dalam menjelaskan cara melaksanakan permainan Permainan

Seperti halnya pada siklus pertama sebelum melaksanakan proses belajar mengajar, ada beberapa hal yang harus dipersiapkan diantaranya:

a. Materi yang akan diajarkan.

b. Perangkat pembelajaran seperti: Silabus, Rencana Pelaksanaan Pembelajaran (RPP), dan Lembar Kerja Siswa (LKS).

c. Alat-alat yang akan digunakan dalam percobaan.

d. Instrumen penelitian seperti: lembar keterlaksanaan RPP, lembar aktivitas siswa, dan lembar evaluasi.

2) Tahap Pelaksanaan Tindakan

Pelaksanaan kegiatan belajar mengajar untuk Siklus II dilaksanakan pada tanggal 21 Maret 2015 di Kelas Xb dengan jumlah siswa 20 siswa. Dalam hal ini peneliti bertindak sebagai guru. Adapun proses belajar mengajar terdiri dari beberapa tahapan berikut:

\section{Pendahuluan}

Guru memotivasi siswa dengan demonstrasi memanaskan alat berbahan dalam besi ke api lilin. Setelah itu guru bertanya "mengapa ketika ujung besi dipanaskan, ujung besi yang lain terasa panas juga?" 
kemudian Guru menyampaikan tujuan Penutup

pembelajaran yang ingin dicapai.

Kegiatan Inti

(1) Guru menerangkan sedikit materi pokok sebagai pengetahuan awal siswa.

(2) Guru membagi siswa menjadi 5 kelompok yang masing-masing kelompok beranggotakan kurang lebih 4 orang yang heterogen dan masing-masing anggota kelompok ditandai dengan nomor.

(3) Guru menunjuk siswa yang berkemampuan lebih untuk menjadi ketua kelompok untuk menjadi tutor sebaya pada kelompoknya.

(4) Ketua kelompok memberi penjelasan materi yang sudah disampaikan guru kepada anggota kelompoknya.

(5) Guru membagikan LKS.

(6) Guru membimbing siswa dalam menerjakan LKS untuk kemudian didiskusikan bersama anggota kelompoknya.

(7) Siswa mempresentasikan hasil diskusi dari LKS

(8) Guru memberikan siswa kartu observer yang sudah terlatih. Hasil bernomor yang berisi pertanyaan- penilaian lembar pengelolaan pembelajaran pertanyaan dan menjelaskan cara dan aktivitas siswa pada putaran kedua bermain siswa dengan kartu dapat dilihat pada Tabel 3 dan 4 berikut ini. bernomor.

Dari Tabel 3 di bawah dapat

(9) Guru membagikan soal tes formatif diketahui nilai rata-rata termasuk kategori untuk evaluasi.

(1) Guru membimbing siswa untuk menyimpulkan hasil pembelajaran yang telah diterima melalui tanya jawab dengan siswa.

(2) Guru memberi penghargaan kepada masing-masing kelompok dengan pujian dan tepuk tangan.

3) Tahap Evaluasi dan Pengamatan

Dari hasil tes evaluasi yang diberikan pada siswa menghasilkan data ketuntasan belajar siswa dari 32 siswa terdapat 22 siswa yang tuntas atau mendapat nilai $\geq 65$. Dengan demikian persentase (ketuntasan kelas) dapat diketahuisebesar $70 \%$.Hasil ini menunjukkan bahwa pada Siklus II ini ketuntasan belajar secara klasikal telah mengalami peningkatan sedikit lebih baik dari Siklus I. Adanya peningkatan hasil belajar siswa ini karena adanya refleksi dan revisi pada siklus I.

Selama kegiatan belajar mengajar pengelolaan pembelajaran kooperatif tipe siswa. Pengamatan ini dilakukan oleh dua 
Cukup Baik, Dengan diperoleh nilai ratarata 3,25 .

Tabel 3 Data Pengamatan Pembelajaran Kooperatif tipe TGT dengan tutor sebaya Siklus II

\begin{tabular}{|c|c|c|c|c|c|}
\hline \multirow[t]{2}{*}{ NO } & \multirow{2}{*}{$\begin{array}{c}\text { Aspek } \\
\text { yang } \\
\text { diamati }\end{array}$} & \multicolumn{4}{|c|}{ Pertemuan II } \\
\hline & & P1 & $\mathbf{P 2}$ & $\begin{array}{c}\text { Rer } \\
\text { ata }\end{array}$ & $\begin{array}{c}\text { Katego } \\
\text { ri }\end{array}$ \\
\hline A & $\begin{array}{l}\text { Pendah } \\
\text { uluan }\end{array}$ & 3,00 & 3,50 & 3,25 & Cukup \\
\hline B & $\begin{array}{l}\text { Kegiata } \\
n \text { inti }\end{array}$ & 3,28 & 2,57 & 2,92 & Kurang \\
\hline $\mathrm{C}$ & Penutup & 3,50 & 3,50 & 3,50 & Baik \\
\hline D & $\begin{array}{l}\text { Pengelo } \\
\text { laan } \\
\text { waktu }\end{array}$ & 3,50 & 3,50 & 3,50 & Baik \\
\hline $\mathrm{E}$ & $\begin{array}{l}\text { Pengelo } \\
\text { laan } \\
\text { KBM }\end{array}$ & 3,00 & 3,25 & 3,12 & Cukup \\
\hline & $\begin{array}{l}\text { Rata- } \\
\text { rata }\end{array}$ & & & 3,25 & \\
\hline
\end{tabular}

Tabel 4 Data Pengamatan Aktivitas Siswa Siklus II

\begin{tabular}{ccccccccc}
\hline $\mathbf{P}$ & \multicolumn{9}{c}{ Aktivitas Siswa } & \multicolumn{3}{c}{ Jml } \\
& $\mathbf{1}$ & $\mathbf{2}$ & $\mathbf{3}$ & $\mathbf{4}$ & $\mathbf{5}$ & $\mathbf{6}$ & $\mathbf{7}$ & \\
\hline I & 8 & 6 & 14 & 15 & 6 & 7 & 8 & 64 \\
II & 10 & 6 & 14 & 16 & 5 & 7 & 7 & 65 \\
\hline $\begin{array}{l}\text { Rata- } \\
\text { rata }\end{array}$ & 9 & 6 & 14 & 15 & 5 & 7 & 7 & 64 \\
\hline $\begin{array}{l}\text { Perse } \\
\text { ntase }\end{array}$ & 13 & 9 & 21 & 24 & 8 & 10 & 11 & 10 \\
\hline
\end{tabular}

Keterangan:

1. Membaca, mendengar penjelasan guru (mencari informasi dan sebagainya)

2. Mendiskusikan tugas/bekerjasama dengan baik dalam tim

3. Melakukan percobaan dan pengamatan dengan menggunakan alat yang sudah ditentukan.
4. Melakukan Permainan dengan kartukartu bernomor

5. Bertanya kepada guru

6. Mempresentasikan hasil percobaan dan pengamatan dengan baik.

7. Menyampaikan pendapat/mengomunikasikan informasi kepada kelas atau guru

4). Tahap Refleksi

Setelah tahap kegiatan dan pengamatan, diperoleh gambaran tentang kekurangan yang terjadi pada putaran kedua sebagai berikut:

a. Guru sudah mulai menguasai kelas, artinya keadaan kelas lebih baik di bandingkan siklus I walaupun masih belum maksimal karena siswa yang tuntas masih kurang dari $85 \%$.

b. Aktivitas siswa pada siklus ini masih belum maksimal, karena siswa dalam mendiskusikan tugas/bekerjasama dengan baik dalam tim belum terlaksana dengan baik.

c. Siswa pada siklus II sudah mengerti dengan pelaksanaan permainan dan sudah maksimal dalam mendiskusikan pelajaran dengan kelompok.

5). Tahap Revisi

Kekurangan-kekurangan yang terjadi pada Pertemuan II di atas akan dijadikan masukan untuk dilakukan revisi pada Pertemuan III yaitu: 
a. Guru lebih maksimal dalam Pembelajaran (RPP), soal Permainan mengelola kelas untuk mencapai dan Lembar Kerja Siswa (LKS). ketuntasan belajar.

c. Alat-alat yang akan digunakan dalam

b. Guru memaksimalkan aktivitas siswa percobaan. dengan memberi nasehat bahwa mereka harus bekerjasama dalam kelompoknya masing-masing dan yang paling baik akan mendapatkan hadiah yang lebih menarik.

d. Instrumen penelitian seperti: lembar keterlaksanaan RPP, lembar aktivitas siswa, dan lembar evaluasi.

2). Tahap Pelaksanaan Tindakan

Pelaksanaan kegiatan belajar

c. Siklus III

1). Tahap Perencanaan

mengajar untuk Siklus III dilaksanakan pada tanggal 28 Maret 2015 di Kelas Xb

Pada siklus ketiga ini tahap perencanaan dilakukan berdasarkan revisi pada siklus pertama. Yang perlu diperbaiki adalah:

Kemampuan guru dalam mengelola
waktu dengan jumlah siswa 20 siswa. Dalam hal ini peneliti bertindak sebagai guru. Adapun proses belajar mengajar terdiri dari beberapa tahapan berikut:

\section{Pendahuluan}

Guru memberikan motivasi dengan

b) Kemampuan guru dalam mengelola demonstrasi mendekatkan tangan ke api kelas

lilin. Kemudian bertanya "mengapa ketika

c)

Kemampuan guru dalam
tangan didekatkan ke sekitar api lilin terasa memaksimalkan siswa dalam hangat?"Guru menyampaikan tujuan mendiskusikan tugas/bekerjasama pembelajaran yang ingin dicapai dalam dengan baik dalam tim sehingga pembelajaran.

masalah dalam kelompok dapat Kegiatan Inti

terselesaikan tepat waktu. 1 . Guru menerangkan sedikit materi

Seperti halnya pada siklus pertama pokok sebagai pengetahuan awal dan kedua sebelum melaksanakan proses belajar mengajar pada siklus ketiga, ada beberapa hal yang harus dipersiapkan diantaranya:

a. Materi yang akan diajarkan.

b. Perangkat pembelajaran seperti: Silabus, Rencana Pelaksanaan siswa.

2. Guru membagi siswa menjadi 5 kelompok yang masing-masing kelompok beranggotakan kurang lebih 4 orang yang heterogen dan masing-masing anggota kelompok ditandai dengan nomor. 
3. Guru menunjuk siswa yang Dengan demikian persentase (ketuntasan berkemampuan lebih untuk menjadi kelas) dapat diketahui $85 \%$. rata-rata tes ketua kelompok untuk menjadi tutor formatif sebesar 81 dan dari 32 siswa yang sebaya pada kelompoknya. telah tuntas sebanyak 27 siswa dan 3 siswa

4. Ketua kelompok memberi penjelasan belum mencapai ketuntasan belajar. Maka materi yang sudah disampaikan guru secara klasikal ketuntasan belajar yang kepada anggota kelompoknya.

5. Guru membagikan LKS.

6. Guru membimbing siswa dalam telah tercapai sebesar $85 \%$ (termasuk kategori tuntas). Hasil pada Siklus III ini menerjakan LKS untuk kemudian mengalami peningkatan lebih baik dari didiskusikan bersama anggota kelompoknya.

7. Siswa mempresentasikan hasil diskusi dari LKS

8. Guru memberikan siswa kartu bernomor yang berisi pertanyaanpertanyaan dan menjelaskan cara bermain siswa dengan kartu bernomor.

9. Guru membagikan soal tes formatif untuk evaluasi.

Siklus II. Adanya peningkatan hasil belajar pada Siklus III ini dipengaruhi oleh adanya peningkatan kemampuan guru dalam menerapkan model pembelajaran kooperatif tipe TGT dengan tutor sebaya sehingga siswa menjadi lebih terbiasa dengan pembelajaran seperti ini dan siswa lebih mudah dalam memahami materi yang telah diberikan.

3). Tahap Pengamatan dan Evaluasi

Selama kegiatan belajar mengajar berlangsung, dilakukan pengamatan Penutup

(1) Guru membimbing siswa untuk TGT dengan tutor sebaya dan aktivitas menyimpulkan hasil pembelajaran siswa. Pengamatan ini dilakukan oleh dua yang telah diterima melalui tanya observer yang sudah terlatih. Hasil jawab dengan siswa. penilaian lembar pengelolaan pembelajaran

(2) Guru memberi penghargaan/hadiah dan aktivitas siswa pada putaran pertama pada kelompok yang memiliki skor dapat dilihat pada Tabel 5 dan 6 berikut ini tertinggi.

Dari Tabel 5, dapat diketahui nilai

Dari hasil tes evaluasi yang diberikan rata-rata termasuk ketagori Baik, Dengan pada siswa menghasilkan data ketuntasan diperoleh nilai rata-rata 3,80, bahwa dari 32 belajar siswa dari 32 siswa terdapat 27 siswa terdapat 28 siswa yang tuntas atau siswa yang tuntas atau mendapat nilai $\geq 65$. mendapat nilai $\geq 65$. Dengan dihitung 
persentasenya (ketuntasan kelas) sebagai kategori penghargaan SUPER sedangkan berikut:

$$
\text { Ketuntasan kelas }=\frac{18}{25} \times 100 \%=90 \%
$$

Tabel 5 Data Pengamatan Pembelajaran Kooperatif tipe TGT dengan tutor sebaya Siklus III

\begin{tabular}{|c|c|c|c|c|c|}
\hline \multirow[t]{2}{*}{ NO } & \multirow{2}{*}{$\begin{array}{l}\text { Aspek } \\
\text { yang } \\
\text { diamati }\end{array}$} & \multicolumn{4}{|c|}{ Pertemuan III } \\
\hline & & P1 & $\mathbf{P 2}$ & Rerata & $\begin{array}{l}\text { Kate } \\
\text { gori }\end{array}$ \\
\hline A & $\begin{array}{l}\text { Pendah } \\
\text { uluan }\end{array}$ & 4 & 4 & 4 & Baik \\
\hline B & $\begin{array}{l}\text { Kegiata } \\
n \text { inti }\end{array}$ & 3,5 & 3,9 & 3,7 & Baik \\
\hline $\mathrm{C}$ & Penutup & 4,00 & 4,00 & 4,00 & Baik \\
\hline $\mathrm{D}$ & $\begin{array}{l}\text { Pengelo } \\
\text { laan } \\
\text { waktu }\end{array}$ & 3,50 & 3,50 & 3,50 & Baik \\
\hline $\mathrm{E}$ & $\begin{array}{l}\text { Pengelo } \\
\text { laan } \\
\text { KBM }\end{array}$ & 3,90 & 3,66 & 3,78 & Baik \\
\hline & Rata-rata & & & 80 & Baik \\
\hline
\end{tabular}

Pada tes akhir ketuntasan belajar sebesar $90 \%$ dengan nilai rata-rata 83,8 . Maka dapat dikatakan bahwa ketuntasan belajar siswa dibanding dengan pretes jauh lebih bagus. Jadi, secara klasikal (90\%) siswa tuntas dalam belajarnya.

Analisis Skor Kelompok

Skor kelompok ini diperoleh dari hasil penjumlahan antara poin yang didapat kelompok dalam mengerjakan LKS dengan poin setiap siswa dalam kelompok tersebut dalam mengikuti Permainan. Berikut hasil skor kelompok Celcius, Reamur, Fahrenheit, Kelvin dan Joule.

Berdasarkan Tabel 7., skor perbaikan dapat dilihat bahwa kelompok Celcius memiliki skor rata-rata 21,67 dengan pada kelompok yang lain yaitu Reamur, Fahrenheit, Kelvin, dan joule berkategori HEBAT dengan rata-rata skor 15,67-16,67-

15,67-17,67. Dengan demikian, dari keempat kelompok tersebut yang paling bagus kerjanya adalah kelompok Celcius sehingga berhak mendapatkan penghargaan (hadiah).

\section{Tabel 6 Hasil aktivitas siswa}

\begin{tabular}{clc}
\hline No & \multicolumn{1}{c}{ Uraian } & $\begin{array}{c}\text { Hasil Siklus } \\
\text { III }\end{array}$ \\
\hline 1 & Nilai rata-rata tes & $81 \%$ \\
2 & $\begin{array}{l}\text { formatif } \\
\text { Jumlah siswa yang }\end{array}$ & $17 \%$ \\
3 & $\begin{array}{l}\text { tuntas belajar } \\
\text { Persentase } \\
\text { ketuntasan belajar } \\
\text { secara klasikal }\end{array}$ & \\
\hline
\end{tabular}

Tabel 7 Jumlah Skor

\begin{tabular}{cccccc}
\hline $\begin{array}{c}\text { Nama } \\
\text { Kelompok }\end{array}$ & \multicolumn{3}{c}{$\begin{array}{c}\text { Jumlah } \\
\text { Skor untuk } \\
\text { Siklus }\end{array}$} & $\begin{array}{c}\text { Rata- } \\
\text { rata }\end{array}$ & $\begin{array}{c}\text { Penghargaan } \\
\text { Kelompok }\end{array}$ \\
& I & II & III \\
\hline Celcius & 20 & 23 & 22 & 21,67 & SUPER \\
Reamur & 14 & 13 & 20 & 15,67 & HEBAT \\
Fahrenheit & 15 & 16 & 19 & 16,67 & HEBAT \\
Kelvin & 19 & 14 & 14 & 15,67 & HEBAT \\
Joule & 21 & 17 & 15 & 17,67 & HEBAT \\
\hline
\end{tabular}

1. Keterlaksanaan RPP

Berdasarkan hasil penelitian, pengelolaan pembelajaran mengalami peningkatan hal ini tidak lepas dari peran guru bidang studi dan observer yang selalu mengoreksi dan memberi masukan atas segala kekurangan seperti terlihat pada 
tabel analisis pengamatan pengelolaan pendahuluan, kegiatan inti, penutup, pembelajaran yaitu:

pengelolaan waktu, dan pengelolaan $\mathrm{KBM}$

a. Siklus I

secara berurutan termasuk kategori cukup

Pada Siklus I Tabel 2 aspek yang baik, kurang baik, baik, baik, dan cukup diamati dalam rencana pelaksanaan baik. Sedangkan nilai rata-rata instrumen pembelajaran yaitu pendahuluan, kegiatan keterlaksanaan RPP pada pertemuan ini inti, penutup, pengelolaan waktu, dan adalah 3,25. Hal ini menunjukkan bahwa pengelolaan KBM secara berurutan keterlakasanaan RPP sudah lebih baik termasuk kategori cukup baik, kurang baik, dibandingkan dari siklus I yang artinya cukup baik, kurang baik dan kurang baik, siswa sudah guru maupun siswa sudah bisa rata-rata kemampuan guru (peneliti) dalam melaksanakan model pembelajaran melaksanakan pembelajaran yang meliputi kooperatif tipe TGT dengan metode Tutor lima aspek tersebut di atas cenderung Sebaya dengan baik dan sesuai dengan berkategori kurang baik. Hal ini RPP.

dikarenakan dalam kegiatan inti guru c. Siklus III kurang jelas dalam menerangkan cara Pada Siklus III Tabel 5 semua aspek bermain dengan kartu bernomor. Sehingga yang diamati mengalami peningkatan yaitu siswa masih kebingungan dalam berkategori baik, hal ini melalui usaha guru melaksanakan permainan serta guru masih (peneliti) yang lebih memaksimalkan lagi kurang dalam membimbing kerja dalam mengelola waktu pembelajaran kelompok dan percobaan siswa. Sehingga (pengelolaan KBM), dan aktivitas siswa siswa masih merasa kesulitan dalam yang dapat bekerjasama, bertanggung melakukan percobaannya. Sedangkan nilai jawab dan jujur dalam melaksanakan rata-rata instrumen keterlaksanaan RPP permainan, dan memperjuangkan pada pertemuan ini adalah 2,97. kelompoknya untuk selalu menjadi yang b. Siklus II

Pada Siklus II Tabel 3 kemampuan rata-rata instrumen keterlaksanaan RPP guru (peneliti) ada peningkatan. Hal ini pada pertemuan ini adalah 3,80.

tidak lepas dari guru (peneliti) yang 2. Aktivitas Siswa berusaha untuk memotivasi siswa Untuk aktivitas siswa setelah semaksimal mungkin agar semangat dalam pemberian tindakan sebagai berikut: mengikuti proses pembelajaran sehingga a. Siklus I dalam Siklus II ini aspek yang diamati 
Pada siklus I yang paling menonjol adalah membaca, mendengar penjelasan guru (mencari informasi dan sebagainya) sebesar 20,58\% dan yang paling rendah adalah mendiskusikan tugas bekerja sama dengan baik dalam tim sebesar $6,86 \%$. Hal ini dikarenakan siswa belum kompak dalam berdiskusi bersama kelompoknya, kendala lainnya dikarenakan siswa belum terbiasa dalam mempersentasikan hasil percobaan dan pengamatan. Namun melihat dari keantusiasan siswa dalam melaksanakan permainan, dapat disimpulkan bahwa siswa merasa senang dengan diterapkannya model pembelajaran kooperatif tipe TGT dengan metode Tutor sebaya.

\section{b. Siklus II}

Pada Siklus II yang paling menonjol adalah melakukan percobaan dengan menggunakan alat yang sudah ditentukan sebesar $21,70 \%$, serta yang paling rendah adalah bertanya kepada guru sebesar $8,52 \%$. Hal ini dikarenakan siswa sudah ada teman sebaya yang membantu menjawab pertanyaan jika ada salah satu teman yang lain bertanya (tidak mengerti pada pelajaran) sehingga siswa sudah mampu berdiskusi dengan teman sebayanya jika ada hal yang tidak dimengerti.

c. Siklus III
Pada silklus III yang paling menonjol adalah mendiskusikan tugas/bekerjasama dengan baik dalam tim sebesar $25,42 \%$, serta yang paling rendah adalah bertanya kepada guru sebesar $8,47 \%$. Hal ini dikarenakan siswa sudah saling berinteraksi satu sama lain di dalam kelompoknya, dan ketika salah satu dari tim ada yang tidak faham terhadap materi yang dipelajari maka yang lain menjelaskan sehingga tidak perlu menanyakan langsung kepada guru. Dan siswa merasa senang dalam pelaksanaan pembelajaran karena ada unsur permainan. Jadi peran teman sebagai tutor sebaya dan permainan dalam pembelajaran sangat berpengaruh pada siswa.

3. Ketuntasan Hasil belajar Siswa

Hasil evaluasi siswa yang peneliti peroleh pada ketuntasan hasil belejar siswa sebagai berikut:

\section{a. Pada Siklus I}

Pada Siklus I ketuntasan hasil belajar siswa diperoleh rata-rata 62,5 dengan persentase sebesar $50 \%$ siswa yang tuntas. Hal ini dikarenakan siswa belum menguasai konsep yang telah dipelajari, sehingga siswa masih merasa kesulitan dalam mengerjakan soal dan belum terbiasa dengan teknik permainan.

b. Siklus II

Pada Siklus II mengalami peningkatan sebesar 20\%, dengan diperoleh nilai rata-rata 72 . Hal ini dikarenakan dari beberapa siswa sudah mulai memahami konsep yang telah 
dipelajari, dan sebagian siswa mulai ikut aktif dalam kegiatan pembelajaran.

c. Siklus III

Pada Siklus III mengalami peningkatan sebesar $15 \%$, dengan nilai rata-rata 81. Dan hasil evaluasi pretespostes mengalami peningkatan dari $10,00 \%$ (2 siswa yang tuntas) menjadi $90,00 \%$. Dengan rata-rata nilai pada pretes sebesar 48 dan postes sebesar 83,8.Hal ini disebabkan hampir seluruh siswa memahami konsep yang telah dipelajari, karena siswa mulai terbiasa belajar bersama dalam kelompok. Disamping itu, sebagian besar siswa telah ikut aktif dalam kegiatan pembelajaran dan guru pengajar mulai berhasil mengelola kegiatan pembelajaran, dimana guru telah mampu memotivasi siswa untuk belajar. Dari hasi penelitian terlihat bahwa peningkatan ketuntasan belajar siswa telah tercapai dengan menggunakan model pembelajaran kooperatif tipe TGT dengan metode Tutor Sebaya.

\section{SIMPULAN}

Berdasarkan data hasil penelitian dan pembahasan yang telah diperoleh, maka dapat disimpulkan bahwa:

1. Hasil belajar siswa melalui penerapan Model Pembelajaran Kooperatif tipe TGT dengan Metode Tutor Sebaya pada kelas X IPA 6 SMAN 2 Pamekasan dapat dikatakan tuntas dengan persentase $50 \%$ pada siklus $1,70 \%$ pada siklus 2 , dan $85 \%$ pada siklus 3 .

2. Aktivitas siswa sangat antusias dalam bertanya, menanggapi pertanyaan dan sangat interaktif selama penerapan model pembelajaran kooperatif tipe TGT dengan metode tutor sebaya.

\section{DAFTAR RUJUKAN}

Arikunto, S. (2011). Penelitian Tindakan Kelas. Jakarta: Bumi Aksara

Retyno, A. (2013). Implementasi metode pembelajaran tutor sebaya terhadap peningkatan prestasi belajar IPA pokok bahasan alat indra. Skripsi Tidak diterbitkan. Malang: UM

Indriani, D. (2011). Mengenal Ragam Gaya Pembelajaran Efektif. Jogjakarta: diva Press.

Isjoni. (2009). Pembelajaran Kooperatif. Yogyakarta: Pustaka Pelajar

Suri, M. (2012). Penerapan Model Pembelajaran Kooperatif Tipe TGT (Team Game Tournament) pada Siswa Kelas VIII SMP Raudlatul Muta'allimin Karang Penang Sampang. Skripsi Tidak diterbitkan. Malang: UM.

Muhammad. (2011). Pembelajaran Kooperatif. Surabaya: Pusat Sains dan Matematika Sekolah UNESA. 
Momentum: Physics Education Journal. Vol 1, No 1, (2017) 66-82

Sanjaya, W. (2009). Strategi Pembelajarn

Berorentasi Standar Proses

Pendidkan. Jakarta: Kencana

Prenada Media Group.

Uno. (2009). Pendidikan dengan

Pendekatan Baru. Yogyakarta:

Global Ilmu. 